\title{
NorDiNa:
}

\section{Et nordisk mangfold i naturfagdidaktikken}

Velkommen til nr 2 av vårt nordiske tidsskrift NorDiNa. Det aller første nummeret ble presentert på det nordiske forskersymposiet i Aalborg 1. mai dette år. Både tilstrømningen til symposiet og responsen NorDiNa har fått viser at det er behov for, og grunnlag for, nordisk kontakt og samarbeid innen naturfagenes didaktikk og beslektede fagområder. Vi håper at NorDiNa kan fylle en viktig funksjon på dette området.

Dette nummeret inneholder vitenskapelige artikler fra ulike forskningsområder, men også annet aktuelt stoff. Anders Isnes presenterer arbeidet med nye læreplaner i naturfag i Norge, prosessen bak og hva nytt som kommer inn i faget. Vi presenterer også ferske doktorgrader under overskriften 'Recent dissertations'. Til slutt i dette nummer finner du også informasjon om viktige konferanser og symposia på vårt fagområde. Vi håper at dette stoffet sammen med artiklene kan bidra til å øke kunnskap om utvikling og forskning som angår naturfag på tvers av landegrenser i Norden, og inspirere til ytterligere samarbeid.

Artiklene vi har publisert i de to første numrene viser at forskning i naturfagdidaktikk i nordisk sammenheng spenner over et stort og spennende felt. Det viser et mangfold i vår forskning når det gjelder valg av tema, forskningsmetoder og datamateriale. Mange bruker kjente metoder for datainnsamling, slik som spørreskjemaer og intervjuer. I artikkelen av Varpu Eloranta og Eija YliPanula (i dette nr) finner vi en mindre vanlig form for datamateriale; de har analysert barns tegninger med hensyn på hva disse kan fortelle om barnas forhold til landskaper og dyr som finnes i disse. Forskning publisert i NorDiNa omfatter ikke bare barn og unges læring og oppfatninger. Journalister som arbeider med helsespørsmål er i fokus i Sverre Pettersens artikkel (i nr 1). Han har undersøkt deres kompetanse når det gjelder helsespørsmål og vitenskapelighet, og hvilke kilder helsenyheter kommer fra og utfra hvilke kriterier de blir vurdert.

Noen artikler tar for seg elevers læring og hvordan undervisning kan legge til rette for dette. Pernilla Nilssons artikkel (i nr 1) beskriver hvordan barn kommuniserer om og lærer fysikk gjennom læringsaktiviteter relatert til en fornøyelsespark. Sylvia Benckert og hennes medarbeidere skriver også om elevers læring i fysikk (i dette nr), og har undersøkt hvordan ulike kontekster for lærestoffet påvirker elevers motivasjon, læring og kommunikasjon i gruppediskusjoner. Maija Ahtee og Olavi Hakkarainen (i nr 1) rapporterer hvordan rekkefølgen av læringssekvenser er vesentlig for elevers læring, og kan vise til interessante forskjeller mellom yngre og eldre elever i hvordan de forholder seg til problemstillinger om objekters tyngde. 
Lærere spiller en avgjørende rolle i all form for undervisning. Gunilla Mattssons (i nr 1) har tatt for seg svenske læreres didaktiske kompetanse innen teknikk og hvilken betydning denne har for elevenes interesse og motivasjon for teknikkemnet. I sin redegjørelse for prosjektet NORLABDK viser Albert Chr. Paulsen (i nr 1) hvordan man kan kombinere etterutdanning av lærere med forsknings- og utviklingsarbeid i skolen. Læreres rolle i klasserommet er belyst gjennom Sonja Mork sin artikkel (i nr 1) som viser oss hvordan deres innspill i elevenes debatt kan klassifiseres, og hvordan ulike språklige handlinger har ulik funksjon for debatten og elevenes faglige utbytte. Språkets rolle i naturfagundervisningen diskuterer også Erik Knain i sin artikkel (i nr 1), hvor han viser hvordan de to perspektivene Skrive for å Lære og Lære å Skrive er viktige for at elevene skal nå en ny forståelse i naturfag. Dette er spesielt aktuelt siden å kunne uttrykke seg skriftlig er definert som en grunnleggende ferdighet i nye norske læreplaner, noe som blir et anliggende også for naturfaget (se Anders Isnes' orientering).

Elevers holdinger og interesser er et vesentlig område for didaktisk forskning. Gudrún Jónsdóttir belyser i sin artikkel (i nr 1) hvordan jenters interesse for kroppen som naturfaglig tema kan forstås med utgangspunkt i teorier om identitet og opplevelse av risiko og kontroll. Mens hennes forskning er basert på inngående kvalitativt materiale fra noen informanter, tar Camilla Schreiner og Svein Sjøberg for seg spørsmål om holdninger og identitet med utgangspunkt i et stort kvantitativt materiale fra ROSE-undersøkelsen (i dette nr). De viser hvordan materialet peker i retning av en 'mismatch' mellom innhold og verdier innebakt i skolens naturfag og verdier som er viktige for elever i deres yrkesvalg. Materiale fra ROSE presenteres også av Jari Lavonen og medarbeidere i deres artikkel (i dette nr). Her får vi mer spesifikt innblikk i faktorer som er avgjørende for finske elevers interesse for fysikk, og hvordan ulike emner innen faget i ulik grad virker motiverende for elevene. Sverre Pettersen har i sin artikkel (i dette nr) tatt for seg elevers holdninger til alternativ medisin. Hans undersøkelse viser at holdningene til elever som har lest biologi i videregående skole ikke skiller seg fra andre elevers holdninger når det gjelder dette temaet, og forfatteren hevder at biologifaget må sikte mot å gjøre elevene mer kritiske overfor helsestoff i medier.

Store internasjonale undersøkelser gir oss et overblikk over situasjonen i forskjellige land og kan hjelpe oss til bedre å forstå vår egen situasjon når det gjelder naturfag i skolen. Rolf V. Olsen har undersøkt omfattende materiale fra PISA-undersøkelsen, og drøfter i sin artikkel (i nr 1) om det finnes en nordisk dimensjon i resultatene. Han finner en antydning til dette, men også at det er mer belegg for å snakke om en felles profil for land i nord-vestlige deler av Europa. Marit Kjærnsli og hennes medarbeidere stiller spørsmålet "Kan elevene mindre enn før?", og viser i sin artikkel (i dette nr) hvordan resultater fra PISA og TIMSS over tid antyder at elevers kunnskapsnivå er senket i Norge og Sverige, mens det er hevet i Finland.

Vi er glade for å presentere dette manfoldet av forskning i NorDiNa. Å skrive en artikkel er et omfattende arbeid, og vi er takknemlige for den tillitt forfattere har vist oss ved å sende sine manuskripter til et helt nytt tidsskrift. I arbeidet med å etablere og holde en høy faglig standard for NorDiNa er våre referees også svært viktige. De tar på seg ekstra arbeid med å vurdere og kommentere inkomne manuskripter, og har ofte gode innspill som forbedrer artiklene vesentlig. De hjelper oss også med å ta beslutninger om å ikke publisere artikler som ikke holder et godt nok nivå innholdsmessig og presentasjonsmessig, selv om disse beslutningene kan være tunge å ta. Følgende personer har bidratt som referees for NorDiNa så langt: 
Aadu Ott

Albert Chr. Paulsen

Allyson Macdonald

Andreas Quale

Andreas Redfors

Ann Zetterqvist

Astrid B. Eggen

Bjørn Andersson

Bjørn Håland

Britt Lindahl

Cedric Linder

Carl Angell

Christina Kjärrqvist

Doris Jorde

Ellen Henriksen

Else-Marie Staberg
Erik Knain

Frank Back

Gustav Helldén

Hannele Cantell

Hafpór Guđjónsson

Helene Sørensen

Helge Strömdahl

Irmeli Palmberg

Jari Lavonen

Jens Dolin

Jenny Lewis

Jim Donnelly

John Leach

Jonas Emanuelsson

Karl Göran Karlsson
Kerstin Norén

Lars Brian Krogh

Lars D. Østergaard

Margareta Ekborg

Marianne Ødegaard

Marit Kjærnsli

Mats Hagman

Mauri lberg

Odd Valdermo

Per Morten Kind

Pål Kirkeby Hansen

Rie Troelsen

Rolf V. Olsen

Stein Dankert Kolstø

Sverre Pettersen

Vi vil takke dem for deres velvilje og det viktige arbeidet de har gjort for vårt nye tidsskrift. Sammen med forfattere er de vesentlige aktører for driften av tidsskriftet. For at NorDiNa skal kunne fylle sin funksjon også i framtiden, er vi avhengige av dere alle. Vi trenger fortløpende å få inn mange artikler for publisering, samt informasjon om prosjekter, nye avhandlinger og aktuelle konferanser. Videre vil vi be dere spre NorDiNa i deres fagmiljøer, og å oppfordre til å tegne abonnemnet. Det kan gjøres på vår web-side www.naturfagsenteret.no/tidsskrift/nordina. På den måten bidrar dere til at NorDiNa blir et tidsskrift som avspeiler og videreutvikler vårt nordiske mangfold i naturfagdidaktikken.

God lesning!

Med hilsen redaktørene,

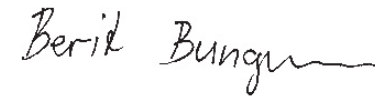

Berit Bungum

Universitetet i Oslo

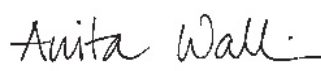

Anita Wallin

Göteborgs universitet

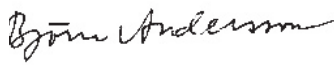

Björn Andersson

Göteborgs universitet 